philosophical botanists so remarkably exhibited in this country at the present time; and to hear it spoken of even by biologists with a covert conternpt.

We make these comments with no desire to detract from the great work which the Board of Studies for the Natural Science School at Oxford is doing, in attempting to elevate Natural Science to a prestige equal to that of theolderstudies at our national universities. In this endeavour we wish them heartily all success, and are fully sensible of their earnest$\mathrm{n} \in \mathrm{Ss}$ to effect this object. But in order to secure success, it is necessary that any mistakes in the early steps must be freely and candidly pointed out, and that the plan of the campaign must be made as faultless as possible. We know that there are those at Oxford who are fully sensible of the deficiencies in the programme to which we have called attention, and who have fought a losing battle for a more thorough and comprehensive, and at the same time more eclectic, plan. We would encourage those to persevere in their endeavours, believing that they must ultimately prevail, and that from this beginning a scheme of instruction in Natural Science will ultimately arise which will be a model for the whole kingdom.

\section{MOUNTAINEERING IN THE SIERRA NEVADA}

Mountaneering in the Sierra Nerida. By Clarence King. (London: Sampson Low, Marston; Low, and Searle, I872.)

A VERY pleasant admixture of science and personal A adventure, from the hand of one who is evidently a sincere lover of nature, and is gifted with considerable descriptive power. Men and manners in the Far West are depicted with much humour; and one chapter, entitled Kaweah's Run, narrating the escape of the author from a couple of brigands who attempted to hunt him down, will show that a Government surveyor's work in America is apt to be more exciting than pleasant. It is a good while since we have read a book so thoroughly unaffected and fresh.; redolent of the clear air of those lofty Sierras where (hear it, ye Alpine climbers, who, in your haunts, daily curse Jupiter Pluvius !) fne weather is the rule. The description of some of Mr. King's scrambles is enough to make the Alpine Club rush off in a body to Mount Whitney; but we cannot help suspecting that his neck would have more than once been safer had he known the rules of that fraternity and carried a good piolet.

Mr. King does not intend his book for a scientific Ireatise, but there are some valuable notes scattered up and down its pages, and with these we must chiefly concern ourselves. The first chapter gives a good sketch of the geology and physical geography of the Sierra Nevada district. It was submerged till Jurassic periods, the ocean shallowing much in the later Triassic time. Then were produced the long mountain waves which stretch from Mexico probably into Alaska, reaching as far east as Middle Wyoming, and forming one broad zone of crumpled ridges, whose westernmost and loftiest member is the Sierra Nevada. Rivers carved the land into cañons, and the sea gnawed its western shores during all the Cretaceous and much of the Tertiary period, in the later part of which the coast ranges were rolled up, facing the Sierra
Nevada, and converting the California valley into a great inlet of the sea. Then, from newer and older ranges alike, began an epoch of furious volcanic activity, till at last the fires burnt low and the greater number went out altogether. To this succeeded a period when, as in North-Western Europe, great glaciers flowed down the valleys, polishing the rocks and leaving behind them a huge trail of moxaine. Now they have shrunk back into snow-fields; and it is only here and there, as about Mount Shasta, that we find any mention of true glaciers in Mr. King's book.

The magnificent cañons, which have more than once been mentioned in the pages of NATURE, are frequently and vividly described. This is the author's opinion of their origin: "Although much is due to this cause (the cutting power of rapid streams) the most impressive passages in the Sierra valleys are actual ruptures of the rock, either the engulfment of masses of great size, as Professor Whitney supposes in explanation of the peculiar form of the Yosemite, or a splitting asunder in yawning cracks. From the summits down half the distance to the plains the cañons are also carved out in broad round curves by glacial action." It may seem presumptuous in one who has never seen the region to differ from $\mathrm{Mr}$. King and his chief, at the same time we cannot help suspecting that here, as in the Alps, it will be shown ultimately that streams have been the principal agents in forming gorges, and that, though they may have been guided by rifts and certainly by joints, no traces of the orisinal fissures can now be found.

Among the scientific "plums" of light description scattered throughout the pudding, we may notice the following:-The granite of some of the mountains of the Yosemite valley exhibits spheroidal structure on a colossal scale, "concentric layers like the peels of an onion each one about two to three feet thick." This structure never descends into the mass for more than a hundred feet. The author notices a peculiar flaky structure on the surface of ice-worn granite (p. 147) developed, as he believes, by the great pressure which it has undergone. A curious case of granite polished by sand friction is also recorded on p. 146 , reminding us of the polished basalt on the shore of Fife. Earth pillars in the cañon of the McCloud glacier (Mount Shasta) are described, "from one to seven hundred feet high, each capped with some hard lava boulder which had protected the soft (trachyte) débris beneath from weakening." A curious cavern in a lava floor in the same region-roughly tubular in shape and more than half a mile long-doubtless produced, like those in Iceland, by the outburst and escape of the still liquid interior of the hardening stream, is worth notice; as well as the fresh-water deposits of a lake which existed through the Cretaceous and Tertiary periods between the Rocky Mountains and the Blue Mountains of Oregon. Nor must we in conclusion forget the humorous tale of how the author, after being sternly rebuked by the palæontologist of the survey for loving snow-peaks better than fossils, repented and found a cephalopod in the auriferous slates of Mount Bullion, and so determined their age. We note but one desideratum, and that is a map, which we trust will be supplied should the book reach, as we hope it will, another edition.

T. G. BONNEY 